\title{
Museology without a Prefix: Some Thoughts on the Epistemology and Methodology of an Integrated Approach
}

Muséologie sans préfixe: quelques réflexions sur l'épistémologie et de la méthodologie d'une approche intégrée

\section{Effrosyni Nomikou}

\section{OpenEdition}

\section{Journals}

\section{Electronic version}

URL: http://journals.openedition.org/iss/640

DOI: $10.4000 /$ iss. 640

ISSN: 2306-4161

Publisher

ICOM - International Council of Museums

\section{Printed version}

Date of publication: 1 June 2015

Number of pages: $203-215$

ISSN: 2309-1290

Electronic reference

Effrosyni Nomikou, «Museology without a Prefix: Some Thoughts on the Epistemology and Methodology of an Integrated Approach », ICOFOM Study Series [Online], 43a | 2015, Online since 06 February 2018, connection on 19 April 2019. URL : http://journals.openedition.org/iss/640 ; DOI : $10.4000 /$ iss.640 


\title{
Museology without a Prefix: Some Thoughts on the Epistemology and Methodology of an Integrated Approach
}

\author{
Effrosyni Nomikou \\ King's College London - United Kingdom
}

\section{Introduction}

The theme of this year's ICOFOM conference, New Approaches to Museology, suggests that museology is expanding. The knowledge base of this distinct field is extending and deepening, enriched by diverse approaches and methods. My paper elaborates on the breadth of an integrated museological domain and examines the subsequent epistemological and methodological implications. The aim of the paper is to join the international dialogue about museology held on the ICOFOM forum by adding a UK (and to a lesser extent US and Australian) museological perspective. It offers an interpretation of prevailing discussions within the English-speaking museums literature, which increasingly recognise the need for assimilation of museological inquiry, theory and practice. The integrity argument presented in this paper is especially influenced by the work of Sharon Macdonald (1998; 2002; 2006a; 2006b), Mark O'Neill (2006) and Andrea Witcomb (2003; 2006), all of whom express a similar museological necessity: the overcoming of futile polarities and bringing museum theory and museum practice into a more meaningful and sustained dialogue.

The first part of this paper makes a case for the conceptualisation and realisation of museology 'without a prefix', namely an integrated, yet distinct field of study that permeates across all dimensions of museological knowledge. It follows the development of museology's coming of age into a discrete discipline, which brought about the conviction that a more integrated approach is currently imperative. According to the proposed 'integrated approach' to museology, binary categorisations such as theory vs. practice are complementary rather than conflicting, and dichotomising attributes such as 'new' vs. 'old', objects vs. people, should no longer hold prescriptive significance. The second part of the paper inspects the implications of such an integrated approach to the epistemology of museology. In short, it explores what and how museology 'knows' (cf. O'Neill 2006). It also tries to identify gaps, shortages or oversights that compromise the integrity of museological knowledge. Subsequently, this paper examines the methodological range suitable to address relevant questions across all aspects of museological knowledge. The special focus of the last section is on the emergence of ethnographic methods in researching the inner functions of museums.

\section{The discipline of museology}

Museology, largely an intellectual product of the $20^{\text {th }}$ century, is a relatively new discipline. Intertwined with the development of the museum institution, museological treatises go back to at least the 
$17^{\text {th }}$ century, ${ }^{137}$ but the forming of the discipline does not happen until two centuries later. The foundations of museology as a distinct body of knowledge are associated with the professionalisation of museum work at the end of the $19^{\text {th }}$ century (Teather, 1991; van Mensch 1992). From this embryonic phase and through its infancy in the early $20^{\text {th }}$ century, museology reached the peak of its early development after the Second World War. From the late 1960s, museology has taken a more theoretical spin and increasingly earned academic standing (Starn, 2005), not always reflected in professional practice (Teather, 1991; van Mensch, 1992). More than four decades onwards, museology has finally 'come of age' (Macdonald, 2006b, p.1). Yet the term still sits uncomfortably in some contexts, not least within English-speaking museum literature, which seems to be more comfortable with the (plural) term 'museum studies' (e.g. Carbonell, 2004; Corsane, 2005; Macdonald, 2006; McLellan, 2003, Marstine, 2006). ${ }^{138}$ Incidentally, among UK universities the term 'museology' is hardly ever used in the titles and descriptions of relevant courses. The etymology and the uses of the term are beyond the scope of this paper. However it is useful to state from the outset that my understanding of museum studies coincides with the favoured description in Desvallées and Mairesse's dictionary which asserts that museology 'includes all the other' definitions of the term given in the dictionary and concerns a 'domain which is freely open to all experiments in the museal field' (2010, pp. 55-56).

So is there consensus? The all-inclusiveness implied in Desvallées and Mairesse's definition could potentially be conclusive for the ontology and epistemology of museology. However, while theory is often detached from practice and vice versa, the 'is it a science?' debate is far from over. This uncertainty is reflected the OED definition: museology is 'the science or practice of organizing, arranging, and managing museums' (emphasis added). In addition, the range of prefixes and/or adjectives for museology, especially in the second half of the $20^{\text {th }}$ century, reveal a tendency to draw boundaries between theory and practice, or partitions within the knowledge domain. What is more, the geographical disparity of use or acceptance of the term (Desvallées \& Mairesse, 2010; GimenezCassina, 2010; Mason, 2006; van Mensch, 1992; 1995), adds to fragmentation in the field with different areas identifying different museological needs, issues and priorities. In the Anglo-Saxon tradition, such fragmentation became most apparent in the aftermath of the advent of the 'new museology' in the 1980s.

\section{When the old museology was new ${ }^{139}$}

'New museology' is a term that is used more frequently and confidently in museums literature than museology. Even so, it is no more clearly defined or specific; like museology, it refers to different things in different regions. A number of 'new museologies' have appeared in various counties and timeframes with varying degrees of success (van Mensch, 1995; Desvallées and Mairesse, 2010). In the Anglophone literature the consensus seems to regard 'new museology' as 'a shorthand for the radical reassessment of the roles of museums in society' (Davis, 1999, p.55), that expressed and responded to the 'widespread dissatisfaction with "the old

\footnotetext{
${ }^{137}$ For example Elias Ashmole's Statutes, Orders and Rules for the Ashmolean Museum in the University of Oxford' (1687) and Johann Daniel Major's Unvorgreiffliches Bedenken von Kunst und Naturalienkammern insgemein (1674).

${ }_{138}$ Personally, I tend to use the terms interchangeably.

${ }^{139}$ Radolph Starn uses a similar play on words in his 'Brief Guide' to museology (2005, p.72)
} 
museology"' (Vergo, 1989b, p. 3). The distinction between new and old was made by theorists in the late 1980s. According to them, 'old museology' had been too narrow and shallow in scope, preoccupied with methods and techniques, and uncritically accepting the universality of the museum institution and the centrality of objects (Starn, 2005; Teather, 1991). Conversely, 'new' became the tag for a reactive attitude towards such old, obsolete, no longer accepted or relevant practices. Yet, the novelty of 'new museology's' criticism towards old-fashioned practices can be contested: similarly breakingthrough challenges and aspirations for change in museums had been previously expressed, when the so-called 'old' museology was in fact new.

Several decades earlier, museum professionals were already concerned with the future of museums, 'professionals' being the key term in this statement. The increasing professionalisation and specialisation of museum work in the beginning of the $20^{\text {th }}$ century brought about shared concern among museum practitioners over practices, functions and purposes of the museum institution. The need for exchanging and collating best practice evidence and guidelines for museum workers was realised in the creation of professional associations (e.g. the Museums Association in the UK, ICOM, etc.) journals and relevant meetings (Bouquet, 2012; Boylan, 2006; Kavanagh, 1994). The introduction of museum courses and qualifications was seen as innovative, in that it would equip future museum professionals with specialist skills that previous generations lacked. Nothing reflects the practical orientation of those museological preoccupations more than the fact that museology became the synonym for professional training of museum personnel (Boylan, 2006; Teather, 1991).

\section{Fragmented museologies}

'New museology', was going to challenge the value of practical and uncritical attitude that was the norm in 'old school' museological training. The focus on practice was deemed too professional and far removed from any theoretical basis (Teather, 1991). This theoretical vacuum was to be filled by the ideology and discourse of cultural theory and postmodern critique. Peter Vergo's eponymous collection of essays (1989a), is considered as the cornerstone of the 'new museology' movement and critical museum theory in the UK (Macdonald, 2006; Mason, 2006; Hooper-Greenhill, 1992). The frequently quoted 'radical re-examination of the role of museums within society and a shift of focus from methods to purposes' (Vergo, 1989 b, p.3), became a reference point among a large proportion of Anglophone museums literature (e.g. Anderson, 2004; Coombes, 1994; Hooper-Greenhill, 1992, Karp \& Lavine, 1991; Karp et al., 1992; 1996; Macdonald \& Fyfe, 1996; MacLean, 1997; Marstine, 2006; Pollock \& Zemmans, 2007; Sherman \& Rogoff, 1994). 'New museology' expressed the 'postmodern scepticism towards 'the museum as metanarrative' (Gorman, 2011), by articulating demands for (among other things) the widening of participation and representation in curatorial practice and the deconstruction of the museum institution (Ames, 1992; Harrison, 2005; Macdonald, 2006b; Pollock, 2007; Stam, 2005). This form of museum criticism adopts the eclecticism inherent in postmodernism, which is considered to enable the emergence of multiple paradigms to coexist.

Postmodernism demarcated a critical language for thinking about museums, but one which has often been rather difficult to translate into practice. There are expectations and interpretations of 'new 
museology', despite its theoretical outset, to be instrumental in radical change in practice (e.g. Ross, 2004; Simon, 2010). Recent research however suggests that, at least in the UK, 'new museology' has failed to impact museums in a way that would constitute a complete departure from familiar practices (McCall \& Gray, 2014). At best, it informs academic curricula and practice initiatives which do not replace the core functions of museums but complement them. The main picture nonetheless tends to be that museums struggle to address demands for social inclusion and representation amidst funding cuts, accountability exercises and introduction of business models that follow 'the cultural logic of late capitalism' (Jameson 1984 cited in Ross 2004, p.100).

The turn of the century found museology in the forefront of a multidisciplinary premise accentuated by the extent of methods and analytical frameworks through which museums are conceptualised. In the last couple of decades, the range of influences in terms of scope and approach has widened significantly (e.g. cultural theory, architecture and design, management and marketing exemplify the range of influences). Yet, this 'expanded and expanding' knowledge base is still in the process of establishing its ontological and epistemological foundations (Macdonald, 2006b, p. 2). What is more, despite the common front of museological interdisciplinarity, 'tribal divisions persist' (Starn, 2005, p.70). Unless the unifying principle of museology is clearly articulated and realised by theorists and practitioners alike (Sola, 1992), these divisions will continue to exist and perpetuate the divide. To overcome the fragmentation that stems from such divides, an argument for museological integration is increasingly gaining support among English-speaking museums literature (e.g. Macdonald, 2006; O’Neill, 2006; Witcomb, 2003).

\section{Museology without a prefix}

The purpose of this overview is not to demonise the heralds or the offerings of new museology. ${ }^{140}$ The analytical concepts and methods deriving from new museology are a significant contribution to museum literature and thinking. Rather, my argument points to an overarching conceptualisation of museology as a study of museum processes (identifying, collecting, exhibiting, preserving, serving, meaning-making, constructing and communicating narratives), their history, and, at the same time, as a translation of these processes into action, professional skills and definitions of best practice. An integrated approach goes beyond side-taking discourses: as much as acknowledging the value of such interventions to challenge, enrich, and develop museological thinking, an integrated approach ought to recognise that they represent one of many interpretations that constitute the realm of museology.

The multi and interdisciplinary setting in which museology currently operates is a fertile ground for the integrated argument to be realised. The revisionist approach of looking 'for differences, for change and for rupture' (Hooper-Greenhill, 1992, pp. 9-10) is progressively abandoned in favour of synthesis and reconciliation (Witcomb, 2003). Museum studies today is starting to move beyond postmodern anxieties, turning towards more consistent and reflective

\footnotetext{
${ }^{140}$ After all, the main influences of my paper are products of this tradition: Macdonald's volume "has its roots in, and takes up the challenge set by [...] "the new museology"' (2006,p. 1), while Witcomb reflects on her own professional practice as 'a curator who identifies with New Museology' (2003,p. 86). The key point is that both authors acknowledge the need for overarching integrity that overcomes the limitations of an attribute (be it 'new' or 'old').
} 
modes (e.g. Macdonald \& Basu, 2007; Bouquet, 2012; Fritsch, 2011). The trail of new 'orthodoxies' that has been left behind by museological side-taking is now being problematized, not least due to the inadequacy of their pragmatism and empirical basis (Macdonald, 2006b, p. 2). For example, the supremacy of the visitor over any other museum aspect, the dominance of interactive exhibits, the questioning of curatorial expertise are some of the premises that are now reconsidered (Macdonald, 2006b; Witcomb, 2006). Museology without a prefix offers a suggestion for a disciplinary framework that seeks out connectedness rather than rupture, and complementary features rather than dichotomies. It scales back the critique that seeks to destabilise and undermine the concept of museum because, as Starn observes, 'the laments and cheers over the loss of tradition and integrity' are long superseded (2005, p. 98).

\section{Integrated epistemology with methodology to match}

The conceptualisation of museology without a prefix - of museology as metanarrative in a sense- implies a certain predisposition towards an all-encompassing museum epistemology. According to the Oxford English Dictionary, epistemology is a 'theory of knowledge and understanding' regarding, in particular, the methods, validity and scope of such knowledge. An epistemology of museology thus concerns the nature and extent of museological knowledge and, it turn, defines its methodology, namely the system of methods through which museological knowledge is produced. It regards, in short, the 'what' and 'how' museology 'knows'. The issue of epistemology of museology has only been sporadically addressed as such in the Anglophone literature (Teather, 1991). In contrast, it has been systematically treated in Francophone and Eastern European museological traditions (e.g. Stransky in van Mensch, 1992). The epistemological argument put forward by Mark O'Neill is perhaps the most attuned to the spirit of an integrated approach to museology (2006). Strictly speaking, O'Neill's thesis is about an epistemology of museums rather than of museology. But the premise on which he establishes his analysis is essentially a problematisation over integrity: the very premise that this paper is built upon. O'Neill identifies three distinct and competing approaches existing in museums (essentialist, adaptive, and ideological) that prohibit coherence, and result in perpetuating fragmentation. To overcome this conflict he proposes an object-based and visitor-centred epistemology of museums:

\footnotetext{
Break[ing] away from an excessively individualistic and dualistic epistemology in order to develop a more participatory and collaborative approach across all dimensions of museum knowledge (p.112).
}

An integrated approach to museology as proposed in this paper exactly matches the participatory and collaborative principle permeating across all dimensions of museological knowledge.

The fourfold scope of museum knowledge presented by O'Neill covers all areas that museology ought to be encompassing: knowledge of objects, of visitors, of museums themselves, and of society. Knowledge of objects and collections is considered the traditional realm of museology; the extent of museums' knowledge and accurate representations- of society on the other hand is much 
more contested. Knowledge of visitors (profile, needs, learning, expectations, and experience) and knowledge of museums (purpose, history, management, finances, organisational culture, staff) complete the spectrum of museological knowledge. Each of these areas is a constituent of the wider domain museological knowledge with great potential for fathom. Their co-existence and cooperation establish epistemological integrity that is imperative for 'an intellectual basis for working across, rather than within, collection boundaries' (O'Neill 2006, p. 103) and, indeed, across knowledge domains.

The substantiation of museum theory with empirical studies, the challenge of critical assumptions and testing of theoretical models signify the transition of museology into a more interdisciplinary phase. In this context, the necessity for systematic empirical accounts of museum processes has been articulated within Anglophone literature (Macdonald, 2002; 2006a, 2006b; Witcomb, 2003; 2006). There is a demand for museology and, consequently, museum policy and best practice guidelines, to be grounded in evidence-based initiatives (Paquette, 2012). Research on museum practices, routines, procedures, and professional conduct is contributing to the maturing of a discipline that has up to recently lacked a coherent epistemology.

The methodological range to match such epistemological demands is to be found across qualitative and quantitative approaches. In terms of choice, the differences between qualitative and quantitative methods are merely 'stylistic' (King et al, 1994, p. 6). What constitutes good research does not reside on the choice of one or the other approach, but on a set of prerequisites that are common to both. These prerequisites include, but are not limited to, the making of descriptive or explanatory inferences, the public disclosure of methodology, the efficiency of the data set one has to examine, the adherence to and consistency of rules and methods. Thus, it is methodological rigour and integrity that constitute the foundations of the discipline of museology. These features should inform the museological practice of academics and practitioners alike.

\section{The example of Visitor Studies}

Knowledge of visitors is an area of museology that has advanced enormously in the last decades. Visitor studies is the exception to the rule of theory-heavy, 'new museology' that prevailed in the UK from 1980s onwards. While influenced by the 'cultural turn' that informed the theory of 'new museology', visitor studies followed a more pragmatic route utilising a range of qualitative and quantitative methods. Investigating museum visitors has become a distinctive, specialised field of empirical analysis with robust data sets and sophisticated research methods (e.g. Bitgood \& Shettel, 1996; Dierking \& Wendy, 1998; Hooper-Greenhill, 1994; 2006; Leinhardt et al., 2002). The increased specialisation is evidenced by the emergence of related professional associations (e.g. Visitor Studies Group, CECA), journals, conferences, and job titles (e.g. audience advocate, audience researcher). The U.S. based Visitor Studies Association defines visitor studies as 'the interdisciplinary study of human experiences within informal learning environments' that entails systematic collection and analysis of data to inform decisions about interpretive exhibits and programs. It could be argued visitors studies' development into a very distinct practice entails the likelihood of fragmentation; the risk that visitor studies becomes another 'new orthodoxy' promoting the supremacy of visitors over the 
other aspects of museums. An integrated approach to museology defies this risk by assimilating visitor studies (and knowledge of visitors that it brings) into one aspect of museology. The example of visitor studies is used here to showcase, on one hand, what other domains of museological knowledge could achieve by employing similar methodological strategies. It also shows how a concept that comes from one area of research can influence thinking and practice across the discipline, illustrating the meaning of interdisciplinarity.

One such example is the concept of 'museum experience', probably the most influential term in museology that comes from visitor studies (Falk \& Dierking, 1992; 2000; 2012). Introduced by John Falk and Lynn Dierking, it refers to 'a continually shifting interaction between physical, personal and social contexts' (1992, p. 6) and is a unique outcome of the 'people-objects' intersection that takes place in museums. The concept came about from the integration of original research in museum ${ }^{141}$ setting with theories of learning coming other of disciplines (mainly psychology and education). As a guiding concept, museum experience offers an enriched understanding of the museum setting moving away from arbitrary assumptions about visits and notions of visitors (e.g. average, information-seeking, nonspecialist etc). Research around the museum experience is ongoing with a number of studies, articles and professional practices having been influenced by the concept. ${ }^{142}$ Recently the original volume by Falk and Dierking was updated to include advances in theory and practice and feature a professional's guide to supporting the museum experience before, during, and after the visit, in an attempt to overcomes the academics vs. practitioners divide (2012).

\section{Research (in) the museum}

The outcome of visitor studies' expansion is an advanced knowledge of visitors that can be felt across the discipline of museology. In comparison, knowledge of museums themselves as institutions has developed on a slower pace, at least with respect to organisational practices and culture. This statement might sound provocative given the activity of professional associations (like ICOM and its subcommittees) that invariably promote exchange of such knowledge. But a certain fragmentation continues to exist since knowledge of museums in their present state has not been as influential to museums theory. Instead, the well-researched history of museums informs much of the criticism on which museum theory is based (e.g. Bennett, 1995; Hooper-Greenhill, 1992). This has created a 'narrative of original sin', in which museums are perceived as static institutions, instruments of ideological hegemonies and power structures and, most importantly, stuck in the past (Witcomb, 2003, p.12). The -usually fair and well-grounded- criticism of historic practices is projected to current praxis. While there are valid points to such criticism, it does not paint the whole picture of museums and so fails to provide relevant criticism at all times. As a result, not only there is a gap in the epistemology of museology, but also practitioners become defensive and protective of their practices (and jobs) hence the fragmentation between academia and professionals persists. One way of addressing this gap and overcoming the theorypractice divide is to employ an empirically-grounded methodological

\footnotetext{
${ }^{141}$ Including science centres, zoos, art galleries, and natural history museums

${ }^{142}$ Probably too many to include in this presentation. For an overview see Kirchberg, V. and Tröndle, M. (2012). Experiencing exhibitions: A review of studies on visitor experiences in museums. Curator 55, pp. 435-452; also Coffee, K. (2007). Audience research and the museum experience as social practice. Museum Management and Curatorship 22, 4.
} 
strategy such as ethnography that would enable the re-examination of museum processes as they happen (Bouquet, 2012).

Ethnography was originally devised as the principal methodological strategy of social and cultural anthropology (Denzin \& Lincoln, 1994) and sociology (Deegan, 2001; Lofland \& Lofland, 1984).Today it is a pervasive research strategy across a range of disciplines that utilises a number of methods, tools and techniques of fieldwork and analysis (Atkinson et al., 2001; Berg, 2004). Its advantage for the study of contemporary practices is its provision of first-hand exploration of research settings that captures the context of social action (Atkinson et al., 2001). Ethnography today is used in a wide range of fieldwork environments from medical settings and education to the study of organisations, media and public sector work. Research in the field of museums and heritage has recently started to take ethnographic directions, reflecting on the demand to explore 'the more subterranean levels of museum enterprise' (Roberts, 1997, p. 127).

In the US, the ground-breaking ethnographic work in museums is the study of Colonial Williamsburg, Virginia conducted by a team of anthropologists (Handler \& Gable, 1997). The aim of the research was to examine the extent to which the radical messages of 'new social history' became common belief and practice in Colonial Williamsburg, and theorise contemporary practice accordingly. Handler and Gable's work offers plenty of insight as a theoretical exercise in museum writing and explores the infinite possibilities and scope of an ethnographic project in a museum setting. Another influential study based on ethnographic methods is the work of educator and cultural historian Lisa Roberts (1997). The example chosen by the author (the making of the Linnaeus Exhibition at the Chicago Botanic Garden) might not in itself be the famous case of innovative museum practice, but her treatise of the museum processes makes the work a distinctive piece of research. Discussing the changing role of educators in museum planning and exhibition development, Roberts insightfully reflects 'on the current situation in museums' (p. 4). It also deals with the importance of the 'real thing' in museum displays, the value of participatory learning experiences and the social transformation of museums. These themes, although not planned in the initial agenda, emerged during the course of the research and became integral part of the study. Such weaving of theoretical concepts and emergent themes is characteristic of the ethnographic method; the agenda is carefully constructed but flexible to include topics that emerge during the fieldwork. The conclusions of ethnography are often unexpected as they reflect the polyphony of world they represent.

In the UK, the pioneer ethnographic project is the study of the Food for Thought exhibition staged in the Science Museum, London (Macdonald, 2002). ${ }^{143}$ The aim of the research was to explore the different definitions of science made by museum staff, reflected in science exhibitions and conceived by the public. The fieldwork covered the period from the early planning stages of the exhibition through to its opening to the public, and documented every aspect of the development process. Macdonald's ethnography is an analysis of cultural construction: conceiving the museum exhibition as a cultural product, the purpose of her research is to 'theorise the business of shaping' such product (2002, p. 94). The use of ethnography allowed

\footnotetext{
${ }^{143}$ Besides the main 2002 publication, methodological reflections and results of the study have appeared in various forms elsewhere (Macdonald, 1992; 2001).
} 
for a fuller account of the nature and complexities of cultural production in the museum because it highlighted the plurality of the organisation through internal workings and politics.

These three studies have in effect been the pillars of the emerging trend of Anglophone museum ethnographies. ${ }^{144}$ The application of ethnographic methodology in a range of settings of museum practice has addressed fundamental museological questions and yielded insightful results about professional culture and organisational change. ${ }^{145}$ In this context, I situated my own doctoral research of the making of the new permanent Money Gallery in the Ashmolean Museum, Oxford (Nomikou 2011; 2013). The major renovation and redisplay project of Britain's oldest museum was an opportunity for new ideas, methods and practices to be implemented. By focusing on the creation of a contemporary numismatic gallery, my aim was to examine how a very traditional museum practice (curating of numismatic collections) and its agents (numismatic curators) respond to and embed museological innovation. I also wanted to examine the implications for curatorial expertise and identity. I followed the process as participant observer from its inception through to its production, implementation and opening of the gallery. My findings demonstrate that conventional practices were not abandoned altogether nor a fundamental transformation of curatorial identity took place. Rather, I documented the formation and operation of a new community of practice (Wenger, 1998): an expansion and diversification of curatorial practice, which assimilated new ideas, other experts' know-how and innovation with existing expertise and experience.

The above studies showcase the potential of ethnographic methodology in museology. As any methodological approach, ethnography is not without its limitations. It is time-consuming enterprise and requires long-term commitment and resources on behalf of the researcher. Funding is not always easy to secure, especially as ethnographies in general do not tend to produce 'a quick fix' to museological problems. A similar criticism is that ethnography fails to feed directly into museum practice due to its concentration on deep theoretical understandings (Hooper-Greenhill 2006). However, this could be turned into an advantage of ethnographic methodology: theorisation grounded on evidence from museum practice is precisely the benefit ethnography adds to an integrated museum epistemology. It corresponds to the demand for more writing from 'well-theorized positions but also from practical experience' in the sector (Witcomb 2003, p. 7). In any case, ethnography is proposed as one of many possible methodological approaches to the different areas of museological knowledge, and is open to refinement and assimilation of other methods.

\footnotetext{
${ }^{144}$ The use of plural here is intentional, for the purposes of disambiguation. 'Museum ethnography', at least in the UK, refers to the practice of working with and researching ethnographic collections in museums (MEG 2001). For the emerging methodological trend I am describing, the term 'heritage ethnography' has also been proposed (Andrews, 2009).

${ }^{45}$ Among them are the following Ph.D. studies: the ethnography at the Bernice Pauahi Bishop Museum in Hawaii (Harrison, 1993, University of Oxford); the ethnography at the Indian Museum in Kolkata (Elliott, 2003, University of Cambridge); the ethnography at the Croydon Museum Service (Hecht, 2004, University College London); the ethnography at the Maritime Museums in Bermuda (Andrews, 2010, University of Cambridge). From a wider heritage perspective, Butler's ethnography of the Bibliotheca Alexandrina project in Egypt touches upon aspects of representation, museum memory and cultural heritage reconstruction with a rigorous methodological framework (2007).
} 


\section{Summing up}

This paper presented an argument for the conceptualisation and realisation of museology as one distinct discipline. It reviewed the development of the discipline from its foundation as the expression of the professionalisation of museum work, its theorisation and association with postmodern discourse, to its maturing into a more integrated enterprise. Museology without a prefix, namely without dichotomising categorisations, operates across museum research, theory, and practice, and constitutes the binding tissue between those domains. It moves beyond polarities and entails distancing from 'an excessively individualistic and dualistic epistemology' (O'Neill, 2006, p.112). Instead, its epistemology consists of knowledge about objects, visitors, museums themselves, communities and society. Each knowledge base is developed both independently and in dialogue with the rest. A commonly expressed view in museums literature is the necessity to substantiate museological arguments in empirical research. A number of methodological approaches are employed to meet this demand. Among them, ethnographic studies are becoming more common gaining increasing recognition as an emerging genre of museum research across the sector.

\section{References}

Anderson, G. (Ed.). (2004). Reinventing the museum: Historical and contemporary perspectives on the paradigm shift. Walnut Creek CA: Altamira Press

Andrews, C. (2009). Heritage Ethnography as a specialised craft: Grasping maritime heritage in Bermuda. In M.L.S. Sørensen and Carman, J. (Eds.), Heritage Studies: Methods and approaches. (pp. 140-163). London: Routledge

Atkinson, P., Delamond, S., Coffey, A., Lofland, J., \& Lofland, L. (2001). Editorial Introduction. In P. Atkinson, S. Delamond, A. Coffey, J. Lofland \& L. Lofland (Eds.), Handbook of Ethnography. (pp.1-7), London; Los Angeles: Sage

Berg, B. (2004). Qualitative Research Methods for the Social Sciences. $5^{\text {th }}$ ed. San Fransisco: Pearson

Bitgood, S., \& Shettel, H. (1996). An overview of Visitor Studies. The Journal of Museum Education 21 (3), 6-10

Bouquet, M. (2012). Museums: A visual anthropology. London and New York: Berg

Boylan, P. (2006). The museum profession. In Macdonald, S. (Ed.) A companion to Museum Studies. (pp. 415-430) Malden, USA; Oxford; Victoria, Canada: Wiley Blackwell

Butler, B. (2007). Return to Alexandria: An ethnography of cultural heritage revivalism and museum memory. Walnut Creek, CA: Left Coast Press

Carbonel, B.M. (Ed.) (2004). Museum studies: an anthology of contexts. Malden, MA; Oxford: Blackwell

Coombes, A.E. (1994). Reinventing Africa: museums, material culture and popular imagination. New Haven; London: Yale University Press

Corsane, G. (Ed.) (2005). Heritage, museums and galleries. Abingdon, Oxon; New York: Routledge

Davis, P. (1999). Ecomuseums: a sense of place. Leicester: Leicester University Press Deegan, M. (2001). The Chicago School. In P. Atkinson, S. Delamond, A. Coffey, J. Lofland, and L. Lofland (Eds.). Handbook of Ethnography. London, Sage

Denzin, N., \& Lincoln, Y. (Eds.). (1994). Handbook of qualitative research. Thousand Oaks, CA: Sage

Dierking, L., \& Wendy, P. (1998). Questioning Assumptions. An introduction to front-end studies in museums. Washington DC: Association of Science-Technology Centres 
Desvallées, A. \& Mairesse F. (Eds.). (2010). Key concepts of Museology. ICOM: Armand Colin

Falk, J., \& Dierking, L. (1992). The museum experience. Washington, D.C.: Whalesback Books.

Falk, J., \& Dierking, L. (2000). Learning from museums: visitor experiences and the making of meaning. Walnut Creek, CA; Oxford: AltaMira Press.

Falk, J., \& Dierking, L. (2012). The Museum Experience Revisited. Walnut Creek, CA: Left Coast Press

Fritsch, J. (Ed.). (2011). Museum gallery interpretation and material culture. New York; London: Routledge

Gorman, J. (2011). Universalism and the new museology: impacts on the ethics of authority and ownership. Museum Management and Curatorship 26 (2), 149-162

Handler, R., \& Gable. E. (1997). The new history in an old museum. Creating the past at Colonial Williamsburg. Durham and London: Duke University Press

Harrison, J. (2005). Ideas of museums in the 1990s. In G. Corsane (Ed.), Heritage, museums and galleries. An introductory reader (pp. 3853). Abingdon, Oxon; New York: Routledge

Hooper-Greenhill, E. (1992). Museums and the shaping of knowledge. London; New York: Routledge

Hooper-Greenhill, E. (1994). Museums and their visitors. London; New York: Routledge

Hooper-Greenhill, E. (2006). Studying visitors. In Macdonald, S. (Ed.) A companion to Museum Studies. (pp. 362-375). Malden, USA; Oxford; Victoria, Canada: Wiley Blackwell

Karp, I., Kreamer, C., \& Lavine, S. (Eds.), 1992. Museums and communities: the politics of public culture. Washington; London: Smithsonian Institution Press.

Karp, I., \& Lavine, S. (Eds.), 1991. Exhibiting cultures: the poetics and politics of museum display. Washington, D.C; London: Smithsonian Institution Press

Kavanagh, G. (Ed.). (1994). Museum provision and professionalism. London and New York: Routledge

King, G., Keohane, R.O.S., \& Verba, S. (1994). Designing social inquiry: Scientific inference in qualitative research. Princeton: Princeton University Press

Leinhardt, G., Crowley, K., \& Knutson, K. (Eds.). (2002). Learning Conversations in Museums. Mahwah, NJ: Lawrence Erlbaum Associates

Lofland, J., \& Lofland, L. (1984). Analyzing social settings: a guide to qualitative observation and analysis. $2^{\text {nd }}$ ed. Belmont, CA: Wadsworth

McCall, V., \& Gray, C. (2014). Museums and the 'new museology': theory, practice and organisational change. Museum Management and Curatorship, 29 (1), 19-35

McLellan, A. (Ed.) (2003). Art and its publics. Museum studies at the Millennium. Oxford: Blackwell

Macdonald, S. (Ed.) 1998. The Politics of Display: Museums, Science, Culture London; New York: Routledge.

Macdonald, S. \& Fyfe, G. (Eds.). (1996). Theorizing museums. London: Blackwell

Macdonald, S. (2002).Behind the scenes at the Science Museum. Oxford; New York: Berg.

Macdonald, S. (Ed.). (2006a). A Companion to Museum Studies. Malden, USA; Oxford; Victoria, Canada: Wiley Blackwell.

Macdonald, S. (2006b). Expanding museum studies: An introduction. In Macdonald, S. (Ed.) A companion to Museum Studies. Malden, USA; Oxford; Victoria, Canada: Wiley Blackwell

Macdonald, S., \& Basu, P. (Eds.). (2007). Exhibition experiments. Malden, MA; Oxford; Carlton, Victoria: Blackwell

Marstine, J. (Ed.). (2006). New museum theory. Oxford: Blackwell

Mason, R. (2006). Cultural theory and museum studies. In Macdonald, S. (Ed.). A companion to Museum Studies. (pp.17-32) Malden, USA; Oxford; Victoria, Canada: Wiley Blackwell 
Nomikou, E. (2011). The other side of the coln Audience consultation and the interpretation of numismatic collections. In J. Fritsch (ed.), Museum gallery interpretation and material culture. (pp. 165-175). New York; London: Routledge

Nomikou, E. (2013). A museological approach to numismatic exhibitions. An exhibition-making ethnography in the Ashmolean Museum. Unpublished PhD thesis, University College London

O'Neill, M. (2006). Essentialism, adaptation and justice: Towards a new epistemology of museums. Museum Management and Curatorship $21(2), 95-116$

Paquette, J. (Ed.) (2012). Cultural policy, work and identity. The creation, renewal and negotiation of professional subjectivities. Farnham: Ashgate

Pollock, G. (2007). Un-framing the modern: Critical space/public possibility. In G. Pollock \& J. Zemans (Eds.). (2007). Museums after modernism. Strategies of engagement. Malden MA, Oxford, Victoria: Blackwell

Roberts, L. (1997). From knowledge to narrative: educators and the changing museum. Washington, D.C. London Smithsonian Institution Press

Ross, M. (2004). Interpreting the new museology. Museum and society 2 (2), 83-104

Simon, N. (2010). The Participatory Museum. Santa Cruz: Museum 2.0

Sherman, D., \& Rogoff, I. (Eds.). (1994). Museum culture: histories, discourses, spectacle. Minneapolis: University of Minnesota Press

Sola, T. (1992). What is museology? Papers in museology 1 (Stockholm) 1019

Starn, R. (2005). A historian's brief guide to new museum studies. The American Historical Review 110 (1), 68-98

Teather, L. (1991). Museum studies. Reflecting on reflective practice. Museum Management and Curatorship 10 (4), 403-417

van Mensch, P. (1992). 'The museology discourse.' Part of PhD thesis: Towards a methodology of museology, University of Zagreb. Available online: http://www.muuseum.ee/en/erialane_areng/museoloogiaalane_ki/p_ van_mensch_towarvan

van Mensch, P. (1995). Magpies on Mount Helicon? ICOFOM Study Series 25, 133-138

Vergo, P. (Ed.). (1989a). The new museology. London: Reaktion.

Vergo, P. (1989b). The reticent object. In P. Vergo (ed.), The new museology. London: Reaktion

Wenger, E. (1998). Communities of practice. Learning, meaning and identity. Cambridge: Cambridge University Press.

Witcomb, A. (2003). Re-imagining the museum: beyond the mausoleum. London: Routledge.

Witcomb, A. (2006). Interactivity: thinking beyond. In Macdonald, S. (ed.) $A$ companion to Museum Studies. (pp. 353-361). Malden, USA; Oxford; Victoria, Canada: Wiley Blackwell

\section{Abstract}

This paper advocates the integrity of museology as a field of study that encompasses all aspects of the museal landscape. Such potential for integrity is based on a far-reaching, yet solid body of research questions, methods and knowledge domains, rather than piecemeal or loosely connected post-modern approaches to the field. A conceptualisation of museology 'without a prefix' promotes an integrated approach and purpose rather than prescriptive frameworks, and operates beyond common museological divides like objects vs. people, academics vs. practitioners, 'old' vs. 'new'. The integrity of museology is (or should be) largely maintained through the substantiation of theory with empirically grounded arguments. This claim brings forward questions about the epistemology and methodology of an integrated approach. From epistemological perspective, the paper examines the scope of museological knowledge, as well as the degree of expertise developed in various domains. In terms of methodology, it outlines current methods, tools and research practices with particular focus on the rise of ethnographic studies. 


\section{Résumé}

Muséologie sans préfixe: quelques réflexions sur l'épistémologie et de la méthodologie d'une approche intégrée

Ce document soutient l'intégrité de la muséologie comme un champ d'étude qui englobe tous les aspects du paysage muséal. Ce potentiel de l'intégrité est basé sur un corps extensif, quoique solide sur des questions de recherche, de méthodes et de domaines de connaissances, plutôt que sur des approches post-modernes sur le terrain qui sont fragmentaires ou légèrement connectées. Une conceptualisation de la muséologie " sans préfixe » favorise l' approche et le but intégrés, plutôt que des cadres normatifs, et dépasse les clivages muséologiques communs comme des objets contre des personnes, des universitaires contre des praticiens, les " anciens " vs les " nouveaux ». L'intégrité de la muséologie est (ou devrait être) largement soutenue par la justification de la théorie avec des arguments empiriquement fondées. Cette affirmation apporte des questions sur l'épistémologie et la méthodologie d'une approche intégrée. Du point de vue épistémologique, la communication examine la portée de la connaissance muséologique, ainsi que le degré d'expertise développé dans divers domaines. En termes de méthodologie, il décrit les méthodes actuelles, des outils et des pratiques de recherche avec un accent particulier sur le lieu d'études ethnographiques. 